\title{
Translating Communities
}

Paul St-Pierre

Université de Montréal

In the year 403 of the Common Era (Letter 71, White 1990), Augustine of Hippo wrote yet again to Jerome, two of his previous letters having gone unanswered. In this latest epistle he reiterates his misgivings about Jerome's undertaking to produce a Latin translation of the Old Testament texts directly from the Hebrew, rather than from the Greek translation of the Septuagint, the version which many considered divinely inspired and which was widely used at the time. Augustine's arguments are based on concerns relating to respect for authority and to the disruption a new and unfamiliar version could introduce. Indeed, whereas Jerome's wish was to produce as true a text as possible, one through which - as he writes - "Latin-speakers might know what was really in the Hebrew text" (Letter 112, White 1990), Augustine wanted first and foremost to retain the text which had the authority of the Church, and of usage, behind it. To get a sense of Augustine's arguments, it is worth quoting from Letter 71 at some length:

[...] I would prefer you to translate the canonical books of Scripture for us from the Greek text which is known as the Septuagint. I feel that many problems would arise if your translation began to be read regularly in many churches, because the Latin churches would be out of step with the Greek ones, especially as anyone who puts forward objections will easily be proved wrong when the Greek text is produced, for Greek is a language almost universally known. If, however, someone were to object to some unusual expression in the version translated from the Hebrew and were to allege that it is wrong, it would be almost impossible to get hold of the Hebrew texts to use in defense of the point to which he objected. But even if it were possible, who would allow so many Latin and Greek authorities to be condemned? In addition, if Hebrew scholars were consulted, they might give a different answer and so you might appear indispensable as the only one who could prove them wrong - but I would be amazed if you could find anyone to arbitrate between you.

Augustine is writing here as an official of the Church, as a bishop with a diocese to administer. He is fearful that Jerome's translation will lead to irresolvable 
doubt and to dissension within and between congregations. If objections arise how are they to be answered, he asks, and who is in a position of sufficient authority to be able to settle disputes. Perhaps even more importantly, even if the Hebrew texts can be obtained and even if the Hebrew texts suggest something different from what is contained in the Septuagint, "who would allow [emphasis added]," he asks, "so many Latin and Greek authorities to be condemned." His belief in the sacred origins of the Septuagint leads him to suggest to Jerome that he should simply correct the errors which have been introduced in the transmission of this text and which Jerome had marked in an earlier translation from the Septuagint, rather than produce a new version, which, by returning to the texts on which the Greek version was based and differing substantially from it, would undermine its authority. Augustine supports his arguments by citing an example of the difficulties Jerome's new translation could cause:

[...] when one of our fellow bishops arranged for your translation to be read in a church in his diocese, they came across a word in your version of the prophet Jonah which you had rendered very differently from the translation with which they were familiar and which, having been read by so many generations, was ingrained in their memories. A great uproar ensued in the congregation, especially among the Greeks who criticized the text and passionately denounced it as wrong, and the bishop (the incident took place in the city of Oea) was compelled to ask the Jews to give evidence. Whether out of ignorance or spite, they replied that this word did occur in the Hebrew manuscripts in exactly the same form as in the Greek and Latin versions. In short, the man was forced to correct the passage in your version as if it were inaccurate since he did not want this crisis to leave him without a congregation.

One year later (Letter 112, White 1990) Jerome responds somewhat acrimoniously to all three letters of Augustine and addresses the charge of a possible mistranslation of one word in the prophet Jonah and the ensuing riot of protest, defending his choice on what are essentially referential grounds. He writes:

You fail to mention what it was that I mistranslated, thereby depriving me of a chance to defend myself; maybe you were afraid that my answer might make it clear that there were no grounds for an objection.

Note that for Jerome the reaction of the congregation and the dissension the translation gave rise to are not sufficient reasons to consider the text in need of 
correction "as if it were inaccurate." Rather, and unlike Augustine, he places the accuracy of the text above all other considerations. He continues:

Perhaps you are referring to the fact that many years ago, 'gourd' cropped up, when Cornelius and Asinius Pollio insisted that I had translated 'ivy' for 'gourd'. I have discussed this problem at greater length in my commentary of the prophet Jonah; now it is enough for me just to say that in the passage where the Septuagint gives 'gourd' and Aquila and the rest translate 'ivy' i.e. kitton, the Hebrew text has 'ciceion' which the Syriac speakers commonly call 'ciceia.' There is a kind of shrub with broad leaves like a pumpkin; when it is planted it grows quickly into a bush without the support of any of the poles or props which cucumber and ivy need, supporting itself on its own stem. If I had wanted to give a literal translation and used the word 'ciceion,' no one would have understood it; if I had translated it as 'gourd' I would be putting something which was not in the Hebrew, so I put 'ivy' to be in agreement with other translators.

For Augustine it is the effect produced by Jerome's translation that is his primary concern. Not only did the bishop of Oea risk losing his congregation entirely, but divisions arose within the congregation, between the Greeks - who were able to refer to the Septuagint - and the Latin-speakers. Jerome's response, however, is at another level entirely and clearly marks the way in which their positions and approaches differ. Rejecting the authority of the Septuagint and of the Latin and Greek authorities - the Church authorities - as the decisive arbiters, which they are for Augustine, he emphasizes the choices which faced him as a translator, namely translate the Hebrew text literally [that is, not translate the word in question] but not be understood, translate following the Septuagint but then use a word not found in the Hebrew text, or translate following "other translators." Jerome rejects the first option out of hand, for reasons that he makes clear in his Commentary on Jonah. There he writes [my translation from Duval 1985: 301]: "And so I wanted, when translating the prophets, to transcribe the Hebrew word itself, since there wasn't this type of plant in Latin. But I was afraid that if I did so professors would use the word for baseless commentary, imagining monsters from India, mountains in Beotia or other such marvels." Not only would a simple transcription not be understood, it would be an occasion for misunderstanding. Opting for the third possibility, for the community of fellow translators, he chooses to follow the original text as closely as possible as interpreted by "Aquila and the rest." This is unsettling for Augustine, for whom the danger lies in the very fact of producing a translation, since to do so is to introduce difference and to put authority into question - ultimately undermining all authority: of the 
Septuagint, of the commentators, of the Church, and of the new translation itself. For Jerome, however, the danger lies in error, in not producing a new translation if one is needed.

There is of course a certain irony in both positions. The Septuagint, the text Augustine feels should at all cost be followed, was itself a translation - although this status was camouflaged and even denied through the myth of its miraculous origins (seventy-two translators, placed in seventy-two separate cells for seventytwo days, and all arriving at exactly the same text), and Jerome's Latin version would itself be adopted as the authoritative text of the Roman Catholic Church at the Council of Trent (1545-1563), more than a thousand years after its production, and this despite its recognized imperfections and errors. Jerome's vernacular version, produced for Latin-speakers, acquired authority only once Latin had become, or was well on its way to becoming, a dead language, at a time when translations into modern vernaculars were being produced as challenges to the authority of the Roman Catholic Church, and in doing so fulfilling Augustine's worst fears.

Within a religious context the translation of foundational sacred texts can be a highly ambiguous act. On the one hand, through making possible more generalized access to the text, translation into the vernacular can facilitate the construction and cohesion of a community of believers; on the other, through the differences between versions which become highlighted through the act of translation, it can also introduce the realization that the text has an historical life, that it changes over time, and this is not easily reconcilable with its sacred status. The potential for error, made evident by and in translation, and its possible effects on the community of believers, represent for Augustine very real dangers and are at the heart of his denial of translation. If he nevertheless accepts that a Latin version be produced from the Greek Septuagint, this is because its accuracy can easily be checked and its subservience to the 'original' remain absolute. In such a case, total reliance on the translation would not be required as it would be for translation from the Hebrew, where the translation functions in the stead of the original; rather, a Latin translation from the Greek would be more like a transparent glass through which the Septuagint would make itself known and continue to exercise its authority. This at least seems to be Augustine's belief and hope, and the basis for his opposition to Jerome's project.

At this point let us turn to more contemporary denials of translation, motivated differently from Augustine's but like his engaging a certain conception of community. 
A well-developed theme in the area of translation studies since the mid-1990s is the ethnocentricity that characterizes much translational activity. Variously known as "naturalization", "domestication", or more traditionally as the "readability" of a translated text, or expressed by writers on translation in statements such as "a translation should be the text the writer would have written had she written directly in the target language", this ethnocentricity of translation points to the habitual priority accorded the values and forms of the language and culture into which a text is being translated. Such priority can at times be relatively benign, but it can also be much less so, as when what is specific to the source language and culture, and in particular to a minority language and culture, is erased through translation. Although this erasure can be a function of the "project" of the individual translator, it does not necessarily need to be, and even an intended act of homage to the language and culture of the original can result in the opposite effect; violence can be endemic to the act of translation itself.

This is perhaps what led a professor at Sambalpur University in Orissa - an eastern coastal state of India whose main language is Oriya - to remark, in response to a presentation on translation I made there some ten or twelve years ago, that Oriya literature should not be translated. Why, he asked, should English be enriched and Oriya impoverished? This reaction surprised and shocked me at the time. How could the act of translation, in and of itself, be considered in such a negative light I wondered, and in what sense is Oriya made poorer by translation? This professor's comment has remained with me over the years; I have not been able to discount it as simply a personal aberration. Recently, I think, I have found an explanation that at least partially addresses the anxiety the professor's reaction gave voice to, and I would like to share it with you. To do this, we will need to transport ourselves to the Queen Charlotte Islands, the home of the Haida, of whom perhaps only a few dozen are still fluent in the Haida language.

In an article in In Translation - Reflections, Refractions, Transformations, Mark Fettes writes of the controversy surrounding the three volumes of translations from classical Haida published by the Canadian poet Robert Bringhurst between 1999 and 2001, in which Bringhurst attempted to demonstrate that the Haida mythtellers were great artists with individual voices. Fettes comments: "By and large, Bringhurst's work was received enthusiastically by literary critics,

(C) Copyrights TranscUlturAl \& Author (2008) 
translators, and authors; somewhat grudgingly and critically by linguists; and with no small degree of hostility by the Haida." (2007: 203) Involved in this hostility, Fettes remarks, are the general questions of voice and appropriation. Fettes feels, however, that there is something more at stake in this reaction, relating to what he calls the "ecological". His reflection on this aspect can perhaps help elucidate the reaction by the professor from Sambalpur.

Fettes notes that "[f]or three of four generations now, the daily life of most Haida people has been conducted in English. Where written literature is concerned, they are part of English-speaking North America. And so, to really understand the significance of Bringhurst's work for the Haida, we must look more closely at literary production and consumption in two very different linguistic ecologies the vanished world of the mythtellers, and contemporary Haida society." (20506) Beyond the lexical and syntactic differences between languages, beyond differences of interpretation, translation is faced with such "ecological" differences, that is differences between languages as social and historical objects in the world and differences in the relations they maintain with their users. Again Fettes (206-07):

English belongs to a class of languages often denoted as 'modern', but which I would prefer - at least in the present context - to call 'metropolitan'. These languages have developed through a long historical process of colonization, in the sense that greater and greater swathes of territory, together with the economic and social systems located on them, have come to be co-ordered through a single more or less standardized linguistic medium. The essence of a metropolitan language is that the vast majority of linguistic devices available to any user are also widely used in genres and discourses which are beyond the influence of that user, or even any group of people directly known to them. [My italics.]

Fettes is arguing here that certain languages, through the process of historical development, become divorced from the communities in which they originated; they gain an abstract existence. Other languages, such as that of the Haida, are intimately connected to the shared direct experience of the particular community in which they are used, even if, and perhaps especially if, this community is becoming smaller and smaller. The German sociologist Ferdinand Tönnies has used the word Gemeinschaft to describe such communities. To translate from a language of a Gemeinschaft community into a metropolitan language of abstraction can be perceived, by the members of the source community, as a form of dispossession and violence. It is worth quoting Fettes here once again:

(C) Copyrights TranscUlturAl \& Author (2008) 
Participation in metropolitan culture is only part of the Haida reality. Living in small island communities as they do, intertwined by multiple webs of familial and clan relationship, they are the heirs of a Gemeinschaft culture also. And this work that is now given back to them [through translation], neatly arranged on the printed page, is not a Gemeinschaft cultural artefact, but only its distant echo. For us, the metropolitans, echoes and distances are what we are used to. But to the Gemeinschaft imagination, they sound like a death knell. (208)

This line of argument and the "ecological" distinctions it draws can be of use in a reflection on the violence implicit in certain acts of translation, even when the translator is sensitive to the specificity of the source language and culture. This violence is that of history itself, mirroring the ways in which communities are made to disappear, absorbed into larger abstractions. Awareness of this effect of history can perhaps give sense to the denial of translation by the professor at Sambalpur, despite all that might distinguish Orissa from the situation of the Haida.

There are some thirty million speakers of Oriya, and it is one of the eighteen Indian languages with special constitutional status. It has a very long tradition of oral and written literature; indeed, one of the principal ways of acceding to social status in Orissa is still through writing, with the result that the number of poets and writers there is proportionally very large. Nevertheless, Oriya is also a language under siege; the effects of globalization, with the privilege it accords metropolitan languages, and one metropolitan language in particular, are being felt. One of the most corrosive of such effects is the devaluation of the local and the regional. The emergence of a cosmopolitan urban middle class in Orissa, alienated from its own language and cultural landscape, has created problems for a traditional society which have not as yet been fully addressed and explored. The rise of schools in which English is used exclusively is in the process of creating an elite which scorns all that is rooted in collective memory and tradition. As a result of globalization, English is emerging as the language of power, the only language worth having. Since without English it would be difficult to obtain employment, more and more families are sending their children to English-language schools, where content and language of instruction confirm the divorce from what is specifically Orissan. Indeed, this is precisely their primary function and ensures their success. This is taking place at the expense of expressions of the local and regional, such as language, history, culture, sense of the past, local practices of childhood, local realities, cultural 
values; at the expense of all that traditionally has served to hold a society together, that has made a community a Gemeinschaft community. As a result students at these schools are increasingly out of touch with where they are, and with their fellow Oriyas, the majority of whom still live and work in rural areas; and these students in the rural areas are in turn being left further and further behind as the society changes. Increasingly, students in English-language schools simply do not have the knowledge, the interest or the idiom to talk about local practices; they are unable to read the Oriya script; they know less and less about the significance of local festivals, care little about local history. Rootless, they belong to an elite whose allegiance is not to any one particular place; they end up being marginalized by, and cutting themselves off from, the rest of the community. At the same time, in the Oriya-language schools, the skills of the English language are hardly taught at all, and as a result the children most often end up illiterate in English. And even those children who do excel in their studies in such schools often suffer from an inferiority complex in terms of socialization and of being able to compete, unable to relate to students from English-language schools on equal terms. Globalization, through the importance accorded English, is creating a divided society in which the future elite is increasingly divorced from its roots.

In such a context, to be translated, and to be translated into English in particular, becomes very important for a writer. It can be a matter of survival, as the readership for Oriya dwindles; it can be a question of access to the pan Indian market, in which only texts in English gain wide circulation; and translation into English can provide a form of recognition lacking in the native Indian languages. Indeed, the two principal literary awards in India - the Jnanpith and the Saraswati Samman - are in reality only open to writers whose work can be read throughout the country, that is to writers whose work has been translated into English. English has become the language worth having, and for a writer value comes from being read in English, or, even more importantly, from his or her work having been published in English independent of whether it is read or not. That value is all the greater if the translations are published under a foreign imprint, with the result that a number of works claim the United Kingdom or the United States as their place of publication although in fact they were produced in India itself.

There is of course a danger - one which is also "ecological" in nature - in such a role given to translation. Not only do the Indian languages become subservient to English, but also the translation of a particular work into English can exert undue influence on the local system of literature. When translation can play a 
role in determining the hierarchies of the original system, an important question becomes who has access to translators and why certain works are selected for translation. Writers whose merit has been recognized within the local system might well have such access, but persons in positions of power - most usually bureaucrats, at least traditionally in Orissa - certainly do have such access and are very often able to make use of it to promote their own literary reputations. In particular when the translator is an outsider, it is important that he or she be aware of the potential effects that choosing to translate a text can have.

A case in point from Oriya literature would be the translation of Gopinath Mohanty's Paraja by Bikram Das, published in the United Kingdom by Faber and Faber in 1987 and in India the same year by Oxford, and described on the back cover of the Indian edition as "[...] the story of a tribal patriarch and his family in the mountainous jungles of Orissa. The slow decline in the fortunes of this family - from the quiet prosperity of a subsistence livelihood towards bondage to the local moneylender - is both poignantly individualized as well as symbolic of the erosion of a whole way of life within peasant communities." The novel belongs to a sub genre of the Oriya novel devoted to representing tribal populations, and although the story is told sympathetically, it is nevertheless told by a non tribal. Even without this translation, Gopinath Mohanty would undoubtedly have been recognized as one of the most important Oriya prose writers of the twentieth century. With the translation, however, the first of an Oriya text into English published outside India, this author has come to eclipse all other modern Oriya writers. Indeed, a recent History of Oriya Literature (Mohanty 2006) devotes more pages to Gopinath Mohanty than to any other modern writer. In this regard it is interesting to compare his literary reputation with that of his elder brother, Kahnucharan Mohanty. A critic for the Indian newspaper The Hindu, Hariharan Balakrishnan, writes: "While Gopinath, the first Jnanpith awardee from Orissa, undoubtedly deserves his place in the firmament, Kahnucharan is considered to be the true successor of Fakirmohan Senapati, 'the father of the Oriya novel'. In a span of 57 years from 1924 to 1982, he [Kahnucharan] wrote an astounding 55 novels and four collections of short stories. He had the rare honour of being made a Fellow of the Sahitya Akademi." (www.hindu.com/ 1r/2007/03/04. Consulted 05 November 2007.) Despite his popular success with contemporary Oriya readers, which was greater than that of his brother Gopinath, Kahnucharan Mohanty has not been translated into English and his reputation, both within Orissa and outside, has suffered as a result.

Note that I am not arguing here against Paraja having been translated or against it having been published abroad. What I am pointing to is the way in which the 
translation of a work can "disturb" a certain "ecological" balance, can play a disruptive role. Disruption and disturbance can of course also be salutary, but they require a familiarity with the literary system which outsiders rarely have. Here it is worth remembering Gayatri Spivak's cautionary remarks about the need for translators - she is talking specifically about Westerners translating works by third world women, but her remarks apply to all translators and to all texts - the need for all translators to have an thorough knowledge of the source literary context:

In my view, the translator from a third world language should be sufficiently in touch with what is going on in literary production in that language to be capable of distinguishing between good and bad writing by women, resistant and conformist writing by women. [...] In other words, the person who is translating must have a tough sense of the specific terrain of the original, so that she can fight the racist assumption that all third world women's writing is good. (1993: 188)

Perhaps for the professor at Sambalpur, to translate from Oriya into English has the effect of wresting artefacts of a community from their cultural anchor and, by transforming them into abstract entities, divesting the community of what belongs to it and constitutes it. The danger of this happening is all the greater when, as is the case here, the target language is in the process of becoming more highly valued than the source within the source community itself. Perhaps translation, and specifically translation into English, in certain colonial contexts or under globalization, produces changes in Gemeinschaft communities in ways which are necessarily violent.

III

It is perhaps easier to offset the violence of appropriation than that inherent in such "ecological" differences, but perhaps even the second can at least partially be addressed through the creation of new Gemeinschaft communities, local communities evolving out of a shared direct experience of translation.

Such seems to have been the hope in Sri Lanka several summers ago, where I was involved in helping set up a translation program at the University of Peradeniya. It was a time of peace and of hope in that country, after almost thirty years of violence, suspicion and oppression. The need for translation, and for translators, between Sinhala and Tamil, had been recognized, and something was being done about it. As such, the desire for translation was a symptom, the 
symptom of the hope for a greater community encompassing its different parts, a community in which both Tamil and Sinhala speakers could work towards a common goal. If, given the renewal of divisions and conflict since the desire and the hope do not seem to have been strong enough, they nevertheless constituted, at least for a moment, the basis on which a larger community could be constructed and in which translation was given a role to play.

In Orissa, the creation of such communities of and by translators also seems highly desirable, as a way of reducing the ecological disturbance introduced by translation and as a way of fostering exchange and dialogue between source and target communities. One can imagine that if the Haida had been actively involved in the translation of their own texts into English the sense of dispossession would have at least been lessened, through the attempt to inflect the metropolitan language in such a way that it could reflect the reality of the Haida experience. So too in the translation from Oriya into English, it is advantageous for translators from both languages to work together, thereby helping to lessen the disruption involved in the transition from Gemeinschaft to abstraction, a transition already taking place in Oriya society and at the heart of the process of translation into a metropolitan language.

My own experience of translation in Orissa supports this view, I believe. Collaboration has for me been a necessity; I regret the obligation but am convinced of its desirability. Not only has the quality of work produced gained from such collaborative efforts, but strong connections - what earlier I have called local communities - have been formed. Some of these have lasted only for the duration of a particular translation; others have continued across several projects and some are still ongoing. More than twenty volumes of translations of Oriya literature have been produced in this manner over the past eight years, published by local, national and international publishers, and new projects are constantly being undertaken. My collaborators have included writers and poets, Oriya academics - mostly from English departments, and people from outside academia as well. In particular, on twelve of the published volumes within the past five years I have worked with Kamalakanta and Leelawati Mohapatra, whose devotion to the promotion of Oriya literature knows no bounds. These different collaborations have made my personal connection to Orissa particularly strong, and more importantly, they have led to a heightened awareness within Orissa of what translation involves, of what it does, and of what it can do. The enormous increase in translation from Oriya into English since the 1990s is probably the sign of the evolution of Orissa from a Gemeinschaft to a metropolitan community, but the possibility of participating in this evolution 
TransclulturAl, vol.1, 1(2008), 1-13

http://ejournals.library.ualberta.ca/index.php/TC

and of playing an active role in channeling this transformation rather than passively submitting to it, with the resulting sense of loss, can perhaps lead to something different. The violence involved in this evolution, and in translation in particular, can perhaps be tempered through the construction of these communities in the interstices between different worlds. 


\section{Bibliography}

Duval, Y.-M., ed. and trans. Jérôme. Commentaire sur Jonas. Paris: Les Editions du Cerf, 1985.

Fettes, Mark. "Language as Sharp as a Knife. Translation in Ecological Context", in In Translation - Reflections, Refractions, Transformations, ed. P. St-Pierre and P.C. Kar, Amsterdam/Philadelphia: John Benjamins, 2007. 2001-211.

Mohanty, J.M. History of Oriya Literature, Bhubaneswar: Vidya, 2006. Spivak, Gayatri C. "The Politics of Translation", in Outside in the Teaching Machine, London/New York: Routledge, 1993. 179-200.

Venuti, Lawence. "Translation, Community, Utopia", in The Translation Studies Reader, ed. L. Venuti, London/New York: Routledge, 2000. 468-488.

White, Carolinne, ed. and trans. The Corespondance (394-419) Between Jerome and Augustine of Hippo, Lewiston/Queenston/Lampeter: The Edwin Meller Press, 1990. 